\title{
IMPLEMENTING THE CONCEPT OF PATIENCE, GRATITUDE, AND A LESSON OF SINCERITY ACCORDING TO JAVA CULTURAL PERSPECTIVE
}

\author{
Sukadari $^{1 *}$, Mahilda Dea Komalasari ${ }^{1}$, Nadea Zulfa Khairunnisa ${ }^{2}$, Azlin Norhaini Mansor ${ }^{3}$ \\ Postgraduate School, Universitas PGRI Yogyakarta, Indonesia ${ }^{1}$ \\ Master of Psychology, Universitas Gadjah Mada, Indonesia ${ }^{2}$ \\ Faculty of Education, Universiti Kebangsaan Malaysia, Malaysia ${ }^{3}$ \\ Corresponding email: sukadariupy@gmail.com
}

\begin{abstract}
The concepts of patience, gratitude, and sincerity are products of local wisdom which are conditional on Javanese cultural values. These three concepts are included in the study of positive psychology that developed in the West, but in their meaning, they are often different from the philosophical foundations of Javanese culture. Unfortunately, the concepts of patience, gratitude, and sincerity in Javanese culture are not widely studied. In this article, the concepts of patience, gratitude, and sincerity will be presented in learning according to the perspective culture of Java. Se others, to deepen this study the authors also outline the concept of patience, gratitude, and sincerity kind of review of psychological or religious. This article uses a literature study where the information collected is obtained through journals, books and other scientific works that can support research topics.
\end{abstract}

Keywords: Patience, Gratitude, Sincerity, Javanese Culture

Article Received: 18 October 2020, Revised: 3 November 2020, Accepted: 24 December 2020

\section{Introduction}

Local wisdom is the values that form of experience or truth of life inherited. This notion is based on the understanding of wisdom workshops according to Wulandari and Hapsari (2018) who state that local knowledge forms of real experience as a result of integration between human, environment, and spirit. Local wisdom also can be interpreted as traditional knowledge about the relationship between society and the environment that gave birth to a value which is then internalized by the community itself. Furthermore, Fajarini (2014) defines local wisdom as knowledge and way of life as a way or strategy in overcoming life problems that are realized by various activities carried out by local communities.

Nowadays, there are different research in technical sciences which are devoted to developing the implementation of the latest innovative findings for the benefits of society (Volodin et al., 2020; Nussupov, et al., 2017). The implementation findings of researchers are reflected in society by behavioural characteristics.
Creating people of high moral character and integrity who adhere to universal values based on moral principles (Varatha Raju \& Thambu, 2020). It is the ultimate goal of the Education Curriculum to develop young people' competences in society (Kassymova et al., 2019; Triyono et al., 2020) and as well as to take care while they are studying something from the start. In this regard, there has been enough research until to date which investigates an appropriate approach to convey teaching as a key requirement and offer useful ideas in the education and industry sectors (Kenzhaliyev et al., 2020). Such approaches need to be able to develop the moral domain set.

Educators pay more attention to upbringing youths via the education system and try to convey traditions. Javanese society is still preserving local wisdom, such as the philosophy of patience, gratitude and sincerity. In connection with the philosophy of life that is believed by the Javanese people, researchers are interested in critically examining the philosophy of life that is patience, gratitude, and sincerity. 


\section{Patience Concept}

Over time, the scientific study of psychology has developed especially positive psychology. Positive psychology is a branch of psychological science which in its development began to glance at eastern values. Indonesia is an eastern country whose people still preserve the values of local wisdom. One of the values of local wisdom is the concept of patience found in the philosophy of Javanese society. According to Yusuf (2018) patiently means the effort to restrain or limit the soul from the desire to achieve something good or noble. Furthermore, Agte and Chiplonkar (2007) define patience as follows: "Patience is defined as calmness, self-control, and willingness or ability to tolerate delay ...". Patience is an attitude that is able to hold emotions and desires and survive in difficult situations that are done without complaining. The individual patient can control themselves as a reflection of the robustness of the soul of the individual.

Patience in English means the word patience, where patience comes from the Latin language patientia which means suffering. Furthermore, the word suffering is defined as a person who experiences something unpleasant or to tolerate the situation (Oxford English Dictionary, 2019). Based on the above definition, the authors conclude the definition of patience, which is the willingness to tolerate the individual's feelings of the negative state that befell him.

In Javanese culture, the concept of patient communication often contained day-to-day as "Wong sabar bakale subur", which means the patient will get a success. There is also a Javanese proverb that says "Wong sabar, rejekine jembar. Wong ngalah, uripe berkah", meaning that people are patient, there are a lot of luck, people who give in their lives will be a blessing. In addition, there are also the principles of Javanese culture also known as "Alon-alon waton kelakon" which means that in achieving goals or desires should be done with perseverance and patience. In everyday life the concept of patience is widely used as a way or strategy in overcoming various psychological problems, such as stress, disaster, dealing with problems, or when someone is experiencing angry emotions (Subandi, 2011).

In a variety of literature, patience is associated with something positive that is felt by individuals. Research conducted by Schnitker \& Emmons (2007) found that individuals with a high level of patience showed lower rates of depression and related to happiness and pleasure. Patience can also increase happiness and reduce one's negative feelings (Ryan \& Deci, 2001). Furthermore, Peterson \& Seligman (2001) states that individuals have the patience have more empathy and fully gratitude. There is a positive relationship between patience, optimism, and hope (Schnitker, 2012). If life satisfaction in people who are patient increases, then depression will decrease.

The concept of patience is widely discussed in Javanese studies (Subandi, 2011) and in the context of religion. In the Qur'an, for example, the word patience is found about 123 times, which are scattered in Surah Makkiyah and Madaniyah (Yusuf, 2018). One of the verses of the Qur'an which teaches the concept of patience in Surah Al-Baqarah Verses 155-156, which means:

"And truly we will give you trials, with a little fear, hunger, lack of wealth, soul and fruit. And give good news to those who are patient so they can (that is) those who, when afflicted by disaster, they say: "Inna lillaahi wa innaa ilaihi raaji'uun (actually we belong to God and only to Him we return)".

The paragraph above is explaining an explicit that when we were hit by the disaster, must be faced with patience so they will gain a better life on the blessing of Allah SWT. The concept of patience is not only stated in the Qur'anic verses but also in Christian teachings. For example, in James 5: 7 this reads:

"Therefore be patient, brothers until the coming of the Lord. See! A farmer waits for valuable fruit from the soil, be patient with it, until he receives the initial rain and the latter rain. 8 You also must be patient and be strong, for the Lord's coming is near!" 
This verse implies that patience is identified with hard work, and perseverance in trying to achieve a goal.

As for Hinduism, patience is also explained, which is contained in "Book of Sarasamuccaya" sloka 94 which means:

"Patience and heart are the main wealth, it is as gold and gems. People who are able to control lust (anger), nothing is beyond glory.

In this book, patience is defined as self-control

In Buddhism, the Dhammapada book, verse 184, the Buddha said:

"Patience is the best practice of asceticism or selfcontrol. Nibbana (Nirvana) is the highest. That is the word of the Buddhas. He who still hurts and persecutes others is actually not an ascetic (samana). "

This verse implies that patience is related to selfcontrol, especially being able to control angry emotions so that the behavior of hurting and abusing others can be avoided as an embodiment of a patient person.

In order to examine the literature relating to the concept of patience, researchers have reviewed several journals. The first is an article written by Subandi (2011) that develops the concept of patience. In the article explained in detail how the concept of patience is reviewed from various religious works of literature. What's interesting is that the article develops aspects of patience based on empirical data. The five aspects are (1) selfcontrol: that is able to hold emotions and desires, forgive mistakes, think long, and tolerance for procrastination (2) fortitude: able to survive in difficult situations and not complain, (3) persistence: work hard, tenacious to find goals and problem-solving (4) accept the reality with sincerity and gratitude, and (5) remain calm: not rush in acting.

Second is an article written by Schnitker (2012), concerning the relationship between spirituality, religiosity, and patience. Schnitker (2012) defines patience as one's tendency to wait quietly when experiencing difficulties, frustration, or suffering. The measuring instrument used to measure patience is to use a 3-factor scale from Schnitker
(2012). This patience questionnaire consists of 11 items consisting of three dimensions, namely: 1) Dimension of interpersonal patience is an attitude that is able to tolerate others in social relationships, 2) Dimensions of life difficulties that are defined as one's ability to overcome challenging life experiences, and 3) Dimension of daily hassles (Patience in everyday life) that is described as a situation that waits in everyday life such as waiting in a queue, congestion. Items are rated from range 1 (Very unlike to me) to 5 (Very similar to me). The results showed that spirituality and religion had a positive relationship with the level of patience and emotional regulation strategies.

The third is an article written by Eliusuk and Izgar (2017) who studied the effect of endurance training on patience and welfare (well-being). In his research sample 30 students from Erbaka University, Konya Province, Turkey. The patience scale uses a scale developed by Schnitker (2010) then adapted to Turkey. The patience scale consists of three dimensions, namely the dimensions of interpersonal patience, the dimensions of life difficulties, and the dimensions of hassles every day (Patience in everyday life). The training consisted of 10 sessions intended for the experimental group, while the control group was not given any treatment. To measure the level of patience and well-being, measurements are taken before training. After the training, it is measured again to see the changes after one week and measured again three months later. The results showed that patience training significantly affected the level of patience but well being.

\section{Gratitude Concept}

The concept of gratitude has been widely used in both cultural and religious contexts. In Western psychology, the concept of gratitude has also been widely studied in positive psychology. In its development, Emmons \& McCullough (2004) explain that the concept of gratitude has long been a study of moral philosophers, theologians, and writers who describe gratitude as a superior 
character. According to Peterson \& Seligman (2004) thankfulness (gratitude) is an expression or expression of thanks because the individual gets something good. Gratitude is preceded by the perception that individuals benefit from others and then pleasant emotions form. Furthermore, Emmons et al. (2003) describe the concept of gratitude as a feeling of wonder, appreciation, and gratitude for the good things that individuals get.

In a cultural context, the concept of gratitude has become values that are in line with the cultural construction in which individuals are located (Haryanto and Kertamuda, 2016). One culture that has the concept of gratitude is Javanese culture. In Javanese society, gratitude is an important thing because people believe that gratitude will benefit emotionally.

Gratitude in the Javanese dictionary means " mature nuwun, akeh disawurake, diwrataake, disebar, pating slebar". In the other hand, in Indonesian dictionary, gratitude implies thankfulness to God. Gratitude is interpreted as emotions that describe feelings of relief or pleasure over something. Being grateful means giving thanks. Emotions that occur when someone is grateful because is because the individual feels protected from danger or get a favor. Being grateful means to say thank you to God, thanking you for something. While thanksgiving means thanksgiving, holding rituals like salvation as an expression of gratitude to God.

There are several levels of gratitude, namely: First, humans who deny the blessings of God. Second, is the level of gratitude spoken orally. Humans at this level will say a sentence of gratitude when they get pleasure even though it is only limited to words and not to the appreciation of the heart. Third, is a group of people who are grateful when they get pleasure but whom easily complaining when they get a trial. The fourth is a human being who is able to give thanks both when he gets pleasure and in a state of disaster (Mulder, 2001).

Meanwhile, gratitude is the most basic level of gratitude (Mulder, 2001). Javanese people interpret sense as the core of life. The sense is interpreted as a feeling of intuitive depth in one's soul. The sense is seen as something important, where life would not exist without feeling. The unique thing about the Javanese people is that they feel that they are more important than reason. Sense can reveal the nature of the phenomenal world, where it can only be understood through taste. In Kejawen's view, gratitude has a meaning that is close to Eling which in Indonesian means to remember. Taste here means that by eling will foster a religious sense, a sense of subtle, and a sense of strength so that someone will spiritually have a relationship with God.

In order to examine the literature relating to the gratitude of the Javanese community, researchers have reviewed several references to local journals and studies of journals in the West. Here the researcher finds the difference between local journals where in this case the article is related to the gratitude of Javanese society and the study of Western literature. In local journals more explained how the celebration ceremony as a form of gratitude, while Western journals were more focused on the concept of gratitude itself.

The first article was written by Hidayatulloh (2013) who examines the Islamic perspective the implementation of alms earth as a form of gratitude in Cilacap, Central Java. In the study, it was mentioned that the celebration of alms earth as a form of gratitude for the gift of God for getting food and drinks as a result of farming. It is known that the people in Cisampih Hamlet, Cisampih Regency are still celebrating alms earth because their people are still dependent on agricultural products. In addition, alms earth is also believed to bring safety for the fields and crops so that the harvest will be abundant for the survival of the local community. Interestingly, the study explains the different views between culture and religion wherein the view of religion the earth alms ceremony is considered to be a polytheist. Unfortunately, the journal does not explain more deeply about the concept of gratitude in question but rather explains the pros and cons of the 
implementation of almsgiving in terms of culture and religion.

The second one is research written by Illahi (2017) that examines the wisdom of the Jodangan ritual in Cerme Cave. In the journal mentioned that Cerme Cave is a legacy of Islamic civilization where the Jodangan ritual was held. The results of this study are that the Jodangan ritual can increase the awareness of people's religiosity as a form of obedience and obedience to God. Unfortunately, methodologically this study only used observations and interviews without explaining in more detail the procedures contained in qualitative research.

The third is a study conducted by Watkins et al. (2003) regarding dimensions of gratitude, abundance, appreciation of simple pleasure and appreciation the others. The concept of gratitude is based on the Gratitude GQ-6 (GRAT) scale developed by Watkins et al in (2003). As for the explanation of the three dimensions, namely: 1) Sense of abundance that is referring to the individual's feeling that his life is always given abundant grace and fortune. The existence of these feelings makes individuals not feel lacking because they believe that what they have received is enough than desired. Appreciation of simple pleasure is respecting of oneself to the business or things that have been done even though it is very simple. Appreciation of others is a form of individual appreciation that is given to others for the contribution they have made. Furthermore, he also explained that giving appreciation is important as a form of gratitude.

\section{Sincerity Concept}

In Javanese society, the concept of sincerity has been passed down from generation to generation so that it becomes an inseparable part of acting or behaving. According to Mulder (1996) sincerity is defined as the attitude of accepting everything in his life and thanking God for his gift because he has faith that everything that happened has become his destiny. This definition implies that an attitude of sincerity will foster inner peace and peace because there is the awareness that everything that happens is a fate that is thankful for. In line with the above opinion, sincerity as accepting as it is.

Sincerity attitude cannot be separated from emotional aspects, as Sastrosupono (1984) argues that sincerity is formed from the elements of patience and willingness as values that have been taken over by the people of Java. Furthermore, Subandi (2011) defines sincerity (self-acceptance) as an attitude that accepts God's destiny and accepts everything that cannot be changed.

This sincerity philosophy is not only applied in a cultural context but also in religion. For example in Islam, inculcating the attitude of sincerity as a value in life, as follows:

... Say: "Allah is enough for me". To be trust in those who surrender themselves. (Surah AzZumar: 38)

In the verse explains that Islam teaches people to surrender themselves to surrender their destiny to God after doing business. The concept of sincerity is used as a strategy in solving life problems so that the perpetrators feel emotionally calm in addressing a problem.

In connection with the sincerity philosophy, the author has reviewed a number of studies which can support the study of this literature regarding the sincerity concept. The author uses Google's search engine to search for literature related to the sincerity concept. As far as the writer has found, Western literature that discusses the concept of sincerity has not been found. The word sincerity when translated in English, namely acquiescent to owns fate, is not found in any scientific article. Or when the writer tries to use the word acceptance to translate the word sincerity, the meaning will be different from the real meaning of sincerity. The author believes that sincerity is a philosophy that only belongs to the Javanese people so it is very interesting to study more deeply.

In order to deepen the discussion of the concept of sincerity, researchers have reviewed some literature about the concept. First, an article was written by Krismawati (2013) who examines the concept note of resignation in education Kristen 
based on the reviews psychologically. In the article that explains that the concept of sincerity has both positive and negative consequences. The positive consequences of developing are the value of humility, patience, and self-control. While the negative consequences of sincerity attitudes among others are the inhibition of initiative and the attitude of easy to give up. The interesting thing in the article is to explain the historical review of the formation of sincerity attitudes in Javanese society. The existence of this sincerity attitude is one of them as a result of the suffering during the colonial era which for three hundred and fifty years made Javanese people inherit attitudes that always succumb to the situation. This attitude is then passed down from generation to generation and sincerity attitudes are formed. In addition, the attitude of Sincerity is also influenced by the values of the kingdom in which the government since ancient times is the royal family. As the people, obedience and obedience to the King (superiors) are highly upheld so that a sincerity attitude was formed in Javanese society. Unfortunately, this article does not explain how the concept of sincerity is more in-depth, one of which does not explain what aspects of the sincerity concept are.

Second is an article written by Wulandari (2018) that explains what the values of the sincerity concept are and its review of the first principle of Pancasila. In the article, it was explained that sincerity contains noble values such as hard work, religiosity, and care for the environment in accordance with the meaning of Godhead. Sincerity philosophy needs to be preserved by promoting character education based on local wisdom. However, this article does not explain more deeply about the concept of sincerity itself.

The third is an article written by Triseptiana and Herdiana (2013) that examines mental health in Javanese female prison inmates. Related to the results of interviews with 6 female prisoners it showed that all respondents have the same understanding of the concept of sincerity. However, an understanding of the concept of sincerity cannot fully represent the mental health of Javanese ethnic women. As for the health aspects, mental fulfilled include adequate bodily desires and Gratify, self-evaluation, adequate life's goal, and integration and consistency of personality, adequate self-knowledge, ability to satisfy the requirements of the group and adequate emancipation from the group or culture. The six aspects of mental health that were not very fulfilled by the respondents included adequate spontaneity and emotionality, the adequate feeling of security, and efficient contact. Their differences in mental health dimensions need due to internal factors and external factors. Unfortunately, the research did not examine in more depth the concept of sincerity, such as not explaining the indicators used by researchers to assess the extent to which a person is said to have a sincerity attitude. This research is only limited to the cognitive realm in discussing the concept of sincerity. It means that the concepts that exist in Javanese society are something that can be observed from behavior.

Based on the discussion above, researchers are interested in the concept of sincerity which contains positive values but on the other hand, has negative stereotypes such as sincerity that are associated with pessimism. However, this negative assumption is a false assumption when viewed from the true meaning of sincerity. Philosophy of sincerity in Javanese society comes from the Javanese version of sincerity ing pandum, makaryo ing nyoto. Sesanti or wise word consists of two sentences which constitute an inseparable unity because if it is separated it will affect the meaning of the philosophy. Nrimo ing pandum means accepting all the gifts of God, while makaryo ing nyoto means working hard. Nrimo ing pandum if not juxtaposed with makaryo ing nyoto sentence often gets a negative assumption, that is, people who are resigned and do not make maximum efforts to achieve their goals. Sincerity sentences that stand alone tend to be interpreted as things that are likely to be pessimistic rather than optimistic. Whereas if the 
two sentences are juxtaposed with nrimo ing pandum, makaryo ing nyoto means resignation to accept all forms of God-given after making the maximum effort done in a hard way.

\section{References}

[1] Agte, V.V. \&Chiplonkar, S.A. (2007). Linkage of Concepts of Good Nutrition in Yoga and Modern Science. Current Science, 92 (7), 956-961.

[2] Eliusuk, A., \& Izgar G. (2017). Effect of The Patience Training Program on Patience and Well-Being Levels of University Students. Journal of Education and Training Studies. 6 (1), $159-168$.

[3] Emmons, R. A., McCullough, M. E. \& Tsang, J-A. (2003). Positive psychological assessment: A handbook of models and measures. United States of America: American Psychological Association.

[4] Emmons, R.A. \& McCullough, L.E. (Eds). (2004). The Psychology of Gratitude. New York: Oxford university Press.

[5] Fajarini, U. (2014). "Peranan Kearifan Lokal Dalam Pendidikan Karakter". Jurnal Sosio Didaktika; Vol.1, No.2.

[6] Haryanto, H, \& Kertamuda (2016). Syukur Sebagai Sebuah Pemaknaan. Jurnal InSight. 18 (2), 109 - 117

[7] Hidayatulloh, F. (2013). Sedekah Bumi Dusun Cisampih Cilacap. Jurnal el Harakah. 15 (1), 1 - 17.

[8] Illahi, M. (2017). Kearifan Ritual Jodangan Dalam Tradisi Islam Nusantara Di Goa Cerme. Jurnal Kebudayaan Islam. 15 (1).

[9] Kassymova G. K., Duisenbayeva Sh. S., Adilbayeva U. B. Khalenova A.,R. Kosherbayeva A. N., Triyono M. B., Sangilbayev O. S. (2019). Cognitive Competence Based on the ELearning. International Journal of Advanced Science and Technology, 28(18), 167 - 177. Retrieved from
http://sersc.org/journals/index.php/IJAST/ article/view/2298

[10] Krismawati, Y. (2013). Falsafah Sincerity" Dalam Budaya Jawa Ditinjau Dari Tugas Pendidikan Kristen Berdasarkan Perspektif Psikologis. Jurnal Teologi dan Pendidikan Agama Kristen, 1 (2) 22 - 34

[11] Lavrinenko, S. V., Arpentieva, M. R., \& Kassymova, G. K. (2019). The negative impact of the internet on the educational process. International youth scientific conference "heat and mass transfer in the thermal control system of technical and technological energy equipment" (HMTTSC 2019). https://doi.org/10.1063/1.5120671

[12] Mulder, Niles. (1996). Pribadi dan Masyarakat di Jawa. Jakarta: Pustaka Sinar Harapan.

[13] Mulder, Niles. (2001). Mistisisme Jawa Ideologi di Indonesia. Yogyakarta: LKIS.

[14] Nussupov, K. K., Beisenkhanov, N. B., Beisembetov, I. K., Kenzhaliev, B. K., Seitov, B. Z., Dulatuly, E., \& Bakranova, D. I. (2017). The formation of Ti x N y and $\mathrm{Ta} \times \mathrm{N}$ y -based diffusion barriers. Materials Today: Proceedings, 4(3), 45344541.

https://doi.org/10.1016/j.matpr.2017.04.02 6

[15] Oxford University Press. (n.d.-a). Patience. In Oxford English Dictionaryonline. Retrieved 20 June, 2019 from http://www.oxforddictionaries .com/us/definition/american_english/patie nce

[16] Peterson, C., \& Seligman, M. E. P. (2004). Character strengths and virtues: $A$ classification and handbook. New York: Oxford University Press/Washington, DC: American Psychological Association.

[17] Peterson, P., N., C., \& Seligman, M. E. P. (2001). Strengths of character and wellbeing. Journal of Social and Clinical Psychology, 23(5), 603-619. 
[18] Poerwadarminta W.J.S. 2003. Kamus Umum Bahasa Indonesia. Jakarta: BalaiPustaka

[19] Ryan, R.M., \& Deci, E.L. (2001). On happiness and human potentials: A review of research on hedonic and eudaimonic well-being. Annual Review of Psychology, 52, 141-166.

[20] Sastrosupono, M., Suprihadi. (1984). Sinkretisme Dan Orang Kristen Jawa, Bandung: Lembaga Literatur Baptis.

[21] Schnitker, S. A. (2010). An examination of patience and well-being. (Dissertation Doctor of Philosophy in Psychology). University of California: Davis.

[22] Schnitker, S.A., \& Emmons, R.A. (2007). Patience as a virtue: Religious and psychological perspectives. Research in the Social Scientific Study of Religion, 18, 177-207.

[23] Schnitker,S. A. (2012). An examination of patience and well-being, The Journal of Positive Psychology: Dedicated to furthering research and promoting good practice, 7(4), 263-280.

[24] Subandi. (2011). Sabar: Sebuah Konsep Psikologi. Jurnal Psikologi UGM. 3(2), 215-227.

[25] Triseptiana, NA., \& Herdiana, I. (2013). Gambaran kesehatan mental narapidana suku jawa ditinjau dari konsep nrimo. Jurnal psikologikepribadian dan sosial, 2, 1 .

[26] Triyono, B.M., Mohib, N., Kassymova, G.K., Pratama, G.N.I.P., Adinda D., Arpentieva, M.R. (2020). The Profile Improvement of Vocational School Teachers' Competencies. Vysshee obrazovanie v Rossii $=$ Higher Education in Russia. Vol. 29, no. 2, pp. 151-158. https://doi.org/10.31992/0869-3617-202029-2-151-158

[27] Varatha Raju, L. D., \& Thambu, N. (2020). Caring moral reasoning through forum theatre in teaching and learning of Moral Education [Penaakulan moral caring melalui teater forum dalam pengajaran dan pembelajaran Pendidikan Moral]. Muallim Journal of Social Sciences and Humanities, 4(2), 214-228. https://doi.org/10.33306/mjssh/75

[28] Volodin V. N., Tuleushev Y. Zh., Kenzhaliyev B. K., Trebukhov S. A. (2020). Thermal degradation of hard alloys of the niobiumcadmium system at low pressure. Kompleksnoe Ispol'zovanie Mineral'nogo syr'â = Complex Use of Mineral Resources $=$ Mineraldik Shikisattardy Keshendi Paidalanu, 1(312), 41-47.

\section{https://doi.org/10.31643/2020/6445.05}

[29] Watkins, P. C., Woodward, K., Stone, T., \& Kolts, R. L. (2003). Gratitude and happiness: development of a measure of gratitude, and relationships with subjective well-being. Social Behavior and Personality: An International Journal, 31(5), 431-451. https://doi.org/10.2224/sbp.2003.31.5.431

[30] Wulandari, Nisa A'rafiyah Tri. (2017). Filosofi Jawa Sincerity Ditinjau dari Sila Ketuhanan Yang Maha Esa. Jurnal Psikologi Kepribadian dan Sosial, 2 (2), 132-138.

[31] Wulandari., Hapsari.(2018). Pop-Up Legenda Sindoro Sumbing Berbasis Kearifan Lokal sebagai Media Literasi Siswa. Jurnal Transformatika. Vol. 2, No. 2.

[32] Yusuf, M., Kahfi, D., \& Chaer M. (2018). Sabar dalam Perspektif Islam dan Barat Jurnal Al-Murrabi, 4 (2). 